\title{
Role of mental state in temporomandibular disorders: A review of the literature
}

\author{
Wojciech Florjański ${ }^{A-D}$, Sylwia Orzeszek ${ }^{(-F}$ \\ Department and Division of Experimental Dentistry, Wroclaw Medical University, Poland \\ A - research concept and design; $\mathrm{B}$ - collection and/or assembly of data; $\mathrm{C}$ - data analysis and interpretation; \\ $D$ - writing the article; $E$ - critical revision of the article; $F$ - final approval of the article
}

Address for correspondence

Wojciech Florjański

E-mail:wojtek.florjanski@gmail.com

Funding sources

None declared

Conflict of interest

None declared

Received on December 5,2020

Reviewed on December 14, 2020

Accepted on February 1, 2021

Published online on March 22, 2021

\begin{abstract}
Temporomandibular disorders (TMD) constitute a heterogeneous group of disorders concerning temporomandibular joints (TMJ) and the surrounding structures. The etiology is multifactorial, and comprises biological factors (e.g., internal derangements in TMJ), psychological factors (e.g., depression, anxiety and stress) and social factors (e.g., a learned response to pain). In accordance with the biopsychosocial model of health and illness, psychological factors are recognized as highly significant in the development of TMD.

The aim of this review was to present the role of chosen mental disorders (depression, anxiety) in TMD and their significance for dental practitioners in the light of current knowledge. The PubMed, Scopus and Web of Science databases were searched for relevant studies. Finally, 22 studies were included in this review. The gathered literature shows convincing evidence that mental derangements play a significant role in TMD by influencing the onset of the disorder, the course of the condition and the patient's response to treatment. However, the precise role of each mental disorder still requires further clarification.
\end{abstract}

Key words: depression, anxiety, temporomandibular disorders, mental disorders

Cite as

Florjański W, Orzeszek S. Role of mental state in temporomandibular disorders: A review of the literature. Dent Med Probl. 2021;58(1):127-133. doi:10.17219/dmp/132978

DOI

$10.17219 / \mathrm{dmp} / 132978$

Copyright

○) 2021 by Wroclaw Medical University This is an article distributed under the terms of the Creative Commons Attribution 3.0 Unported License (CC BY 3.0) (https://creativecommons.org/licenses/by/3.0/). 


\section{Introduction}

'Temporomandibular disorders' (TMD) is an umbrella term for a heterogeneous group of disorders concerning temporomandibular joints (TMJ) and the surrounding structures. Temporomandibular disorders are the second most common cause of pain in the orofacial region after toothache. ${ }^{1}$ The prevalence of TMD in the general population is estimated at around $40 \% .^{2}$ In young adults, the prevalence of TMD symptoms varies from $42.9 \%$ up to $60 \% .^{3-7}$ The most common symptoms are: pain of the masticatory muscle or in the joint area; headache; reduced mobility of the mandible, and joint sounds. ${ }^{8}$ The etiology of TMD is multifactorial, ${ }^{9-11}$ and comprises biological factors (e.g., internal derangements in TMJ), psychological factors (e.g., depression, anxiety and stress) and social factors (e.g., a learned response to pain). ${ }^{12}$ The Research Diagnostic Criteria for Temporomandibular Disorders (RDC/TMD) introduced by Dworkin and LeResche in $1992,{ }^{13}$ later updated to Diagnostic Criteria for Temporomandibular Disorders (DC/TMD), is an internationally accepted tool for diagnosing TMD based on the biopsychosocial model of health and illness. The RDC/TMD and the latest DC/TMD function as a two-axis system. Axis I focuses on diagnosing biological factors based on physical examination, and Axis II refers to psychosocial factors, studied by means of a series of questionnaires. ${ }^{13}$ The two-axis structure proposed in this diagnostic tool brings out the importance of psychosocial factors in TMD, which are still often underestimated or unknown by various clinicians working in the field of dentistry.

The aim of this review was to present the role of chosen mental disorders (depression, anxiety) in TMD and their significance for dental practitioners in the light of current knowledge.

\section{Material and methods}

The authors searched 3 electronic databases - PubMed, Scopus and Web of Science - for articles describing the relationship between anxiety or depression and TMD. Only original, English-language articles were included. Also the bibliography of the obtained studies was searched for relevant articles. Then, the retrieved papers underwent a qualitative analysis. Finally, 22 articles were included in this review.

\section{Results and discussion}

Mental disorders, such as depression or anxiety, are considered by some authors as the potential causes of TMD symptoms. ${ }^{14,15}$ They play an important role in the onset of TMD and its perpetuation. ${ }^{16-18}$ Some authors consider psychosocial comorbid conditions as predictors of a less favorable response to classical therapy. ${ }^{19}$

The precise mechanisms linking psyche and TMD are unknown. Potentially, stress may alter the threshold of pain perception in the central nervous system, increase the intensity of parafunctional habits as well as masticatory muscle fatigue and tightness, and initiate the disorder. ${ }^{14,15}$ Or the other way round - pain (especially chronic), through the constant input of painful stimuli, induces central sensitization and causes permanent changes in the central nervous system. ${ }^{20}$ Pain and psychological distress seem to create a dynamic vicious circle, in which mental disorders intensify the perceived pain and the perceived pain worsens the course of mental disorders. In many cases, it is hard to distinguish the cause from the effect. ${ }^{21}$ The mechanism may also be associated with the dysregulation of the hypothalamic-pituitary-adrenal axis, leading to the production of excessive amounts of stress hormones, such as cortisol and catecholamines. The axis hormones are associated with mental disorders, such as depression, and other somatic illnesses, such as diabetes, hypertension or facial pain. ${ }^{22-24}$ Other studies confirmed that patients diagnosed with TMD presented with statistically significantly higher levels of stress hormones in comparison with healthy controls..$^{25,26}$

\section{Depression}

A depressive episode is characterized by subsequent symptoms: low mood; loss of interest or no sense of pleasure; psychomotor agitation or retardation; fatigue or loss of energy; significant changes in weight; strong belief in own worthlessness or a sense of guilt; impaired concentration; and hypersomnia or insomnia. ${ }^{27-29}$ Patients suffering from depression are at higher risk of committing suicide. $^{30}$

In the last 20 years, the prevalence of depression has increased by $49.86 \%$ and it is estimated that during lifetime, $20 \%$ of the society will develop this illness. ${ }^{31-33}$

The most commonly used questionnaires diagnosing depression are: the Hospital Anxiety and Depression Scale $(\text { HADS })^{1}$; the Patient Health Questionnaire-9 (PHQ-9) ${ }^{34}$; the Symptom Checklist-90-Revised (SCL-90R) ${ }^{35,36}$; and the Beck Depression Inventory (BDI). ${ }^{37}$ The usage of those questionnaires as diagnostic tools is very convenient and time-saving from the point of view of the doctor. Still, it has to be marked that questionnaires can only serve as screening tools for certain psychological disorders, and indicate patients that need a definitive diagnosis and treatment provided by the psychiatrist. ${ }^{1,38}$

Patients with TMD present with higher levels of depression as compared to healthy controls..$^{29,39,40}$ Some studies divided TMD patients based on pain, reporting significantly higher levels of depression in patients 
with painful TMD than in the case of non-painful TMD. ${ }^{36,41,42}$ What is worth noticing in those studies is the fact that the precise localization of pain (diagnosis from Axis I) was not significant. ${ }^{36,41,42}$ Others divided patients based on the duration of the symptoms, reporting significantly higher levels of depression in patients with chronic TMD than those with acute TMD. ${ }^{20,38}$ In the above-mentioned studies, chronic TMD was defined as lasting at least 3 months. One of the studies focused on changes in the perceived symptoms of TMD at the time of higher and lower levels of depression and anxiety. ${ }^{43}$ A significant difference was found only in the maximum mouth opening without pain and the level of self-estimated mandibular impairment. The maximum mouth opening without pain was decreased and the level of self-estimated mandibular impairment was increased at the time of a high level of depression. On the other hand, non-significant differences were found in the number of tender points or the electromyographic activity of the masticatory muscle, which seemed not to depend on the level of anxiety and depression. ${ }^{43}$

Korszun et al. conducted an interesting study, in which patients with chronic facial pain underwent full medical and psychiatric assessment according to the Diagnostic and Statistical Manual of Mental Disorders IV (DSM-IV) criteria. $^{26}$ The percentage of patients diagnosed with depression or symptoms characteristic of depression was statistically significantly higher among patients with chronic facial pain than in healthy controls. Interestingly, fatigue and insomnia were the most common symptoms, reported by $92 \%$ of patients with a diagnosis of depression and $50 \%$ of patients presenting with only some depressive symptoms. By comparison, 38\% of controls reported those symptoms. An important issue is that $50 \%$ of patients fulfilling the DSM-IV criteria for depression received this diagnosis for the first time, despite various previous consultations. This fact might indicate that the number of patients with TMD requiring a specialist psychiatric consultation is underestimated by various practitioners. No statistically significant differences in the occurrence of depression between TMD patients and chronic facial pain patients of different origin was found, either. Thus, the significant variable correlated with depression could be pain, not TMD. ${ }^{26,44}$ Several studies suggest that depression and chronic pain syndromes share the same neurological pathways and neurotransmitters (such as norepinephrine, glutamate and serotonin), and involve the same brain structures (such as the anterior cingulate cortex, the prefrontal cortex, the amygdala, and the hippocampus). ${ }^{45-47}$ Furthermore, both chronic pain and depression aggravate each other, and cause maladaptive changes in the brain function and structure. ${ }^{46,47}$ Chronic pain intensifies depressive symptoms by causing distress. ${ }^{46}$ Depression on the other hand may be a result of monoamine neurotransmitter deficiency, which leads to increased sensitivity to painful stimuli. ${ }^{45}$ It is also suggested that depression may be considered as an inflammatory process in the brain due to increased levels of proinflammatory cytokines, which results in higher pain sensitivity. ${ }^{46}$ Therefore, early diagnosis and proper treatment are crucial.

Another interesting finding is that young children who had contact with adults with depression are at increased risk of the development of painful TMD in their early adulthood. ${ }^{48}$

Table 1 presents a summary of data regarding depression from the most important studies included in the review.

\section{Anxiety}

Anxiety is characterized by a sense of worry, difficult to control and causing a feeling of restlessness, fatigue, a sense of tension, nervousness, and sleep disturbance. ${ }^{27,49}$ In some studies, in which the Spielberger State-Trait Anxiety Inventory (STAI) was used, 2 types of anxiety were distinguished: state-anxiety, which is associated with the current level of anxiety and is transitory; and trait-anxiety, which expresses one's personality and is more stable during lifetime. ${ }^{50}$ Anxiety is recognized as the most common mental disorder in the European Union and it is 3 times more frequently diagnosed in women than men. ${ }^{51}$

Studies employ various questionnaires to diagnose anxiety. These are: $\mathrm{HADS}^{1,37}$; STAI ${ }^{15,37,52,53}$; the Beck Anxiety Inventory (BAI) ${ }^{37,52}$; the Generalized Anxiety Disorder-7 $\left(\right.$ GAD-7) ${ }^{34}$; and SCL-90R. ${ }^{35,36}$

The role of anxiety in TMD is still rather controversial. Many studies suggest the existence of a correlation between TMD and anxiety, 3,37,54-56 but other researchers present contradictory results, ${ }^{1,20,57-59}$ seeing anxiety as a less important factor in the case of TMD patients than depression. ${ }^{1,20}$ The different results of the presented studies may be explained by differences in many important variables, such as the population under study, the study design and the questionnaire used.

Those authors who managed to find a correlation between TMD and anxiety reported significantly higher levels of anxiety in patients with TMD as compared to healthy controls. The individuals affected by anxiety were up to 5 times more prone to develop TMD than nonTMD patients. ${ }^{48}$ A correlation was found in both acute ${ }^{60}$ and chronic TMD. ${ }^{61}$ Severe anxiety levels increased by twice the probability of chronic pain, disability and depression, ${ }^{53}$ and the level of anxiety correlated with the duration of the disorder. ${ }^{20}$

Regarding one of the subtypes of anxiety, the analyzed articles were consistent. Trait-anxiety occurred more often in patients with TMD than healthy controls. ${ }^{15,53}$ 
Table 1. Summary of data regarding depression from the most important studies included in the review

\begin{tabular}{|c|c|c|c|c|c|c|c|}
\hline Study & Population & $\begin{array}{l}\text { Study } \\
\text { group }\end{array}$ & $\begin{array}{l}\text { Control } \\
\text { group }\end{array}$ & $\begin{array}{l}\text { TMD } \\
\text { diagnosing } \\
\text { tool }\end{array}$ & $\begin{array}{l}\text { Psychiatric } \\
\text { diagnosing } \\
\text { tool }\end{array}$ & Correlation & Conclusion \\
\hline $\begin{array}{l}\text { Giannakopoulos et al. } \\
(2010)^{1}\end{array}$ & $\begin{array}{c}N=222 \\
61 \text { men } \\
161 \text { women }\end{array}$ & $\begin{array}{l}\text { chronic, } \\
\text { painful } \\
\text { TMD }\end{array}$ & $\begin{array}{l}\text { non-painful TMD, } \\
\text { patients without } \\
\text { chronic facial pain }\end{array}$ & $\mathrm{RDC} / \mathrm{TMD}$ & HADS & + & $\begin{array}{l}\text { significantly higher levels of depression } \\
\text { in the study group }\end{array}$ \\
\hline $\begin{array}{l}\text { Cao et al. } \\
(2020)^{20}\end{array}$ & $N=830$ & $\begin{array}{l}\text { TMD } \\
\text { subgroups }\end{array}$ & TMD subgroups & $\mathrm{RDC} / \mathrm{TMD}$ & DASS-21 & $+1-$ & $\begin{array}{l}\text { significantly higher levels of depression } \\
\text { only in the chronic, painful TMD subgroup }\end{array}$ \\
\hline $\begin{array}{l}\text { Korszun et al. } \\
(1996)^{26}\end{array}$ & $N=72$ & TMD & $\begin{array}{l}\text { chronic } \\
\text { facial pain }\end{array}$ & $\begin{array}{l}\text { University of } \\
\text { Washington } \\
\text { criteria }\end{array}$ & $\begin{array}{l}\text { psychiatric } \\
\text { examination }\end{array}$ & - & no significant correlation found \\
\hline $\begin{array}{l}\text { Simoen et al. } \\
(2020)^{34}\end{array}$ & $\begin{array}{c}N=243 \\
52 \text { men } \\
191 \text { women }\end{array}$ & $\begin{array}{l}\text { painful } \\
\text { TMD }\end{array}$ & non-TMD & DC/TMD & PSQ-9 & + & $\begin{array}{l}\text { significantly higher levels of depression } \\
\text { in the study group, unrelated to gender }\end{array}$ \\
\hline $\begin{array}{l}\text { De la Torre Canales et al. } \\
(2020)^{36}\end{array}$ & $\begin{array}{c}N=737 \\
150 \text { men } \\
587 \text { women }\end{array}$ & $\begin{array}{l}\text { painful } \\
\text { TMD }\end{array}$ & non-painful TMD & $\mathrm{RDC} / \mathrm{TMD}$ & $S C L-90 R$ & + & $\begin{array}{l}\text { significantly higher levels of depression } \\
\text { in the study group }\end{array}$ \\
\hline $\begin{array}{l}\text { Reiter et al. } \\
(2015)^{38}\end{array}$ & $N=207$ & $\begin{array}{l}\text { chronic } \\
\text { TMD }\end{array}$ & acute TMD & $\mathrm{RDC} / \mathrm{TMD}$ & SCL-90R & + & $\begin{array}{l}\text { significantly higher levels of depression } \\
\text { in the study group, additionally, } \\
\text { more severe pain and disability }\end{array}$ \\
\hline $\begin{array}{l}\text { Fernandes et al. } \\
(2013)^{41}\end{array}$ & $N=224$ & $\begin{array}{l}\text { painful } \\
\text { TMD }\end{array}$ & $\begin{array}{l}\text { non-painful TMD } \\
\text { or non-TMD }\end{array}$ & $\mathrm{RDC} / \mathrm{TMD}$ & SCL-90 & + & $\begin{array}{l}\text { significantly higher levels of severe } \\
\text { depression in the study group }\end{array}$ \\
\hline $\begin{array}{l}\text { Maślak-Bereś et al. } \\
(2019)^{42}\end{array}$ & $N=260$ & $\begin{array}{c}\text { TMD } \\
\text { subgroups }\end{array}$ & non-TMD & $\mathrm{RDC} / \mathrm{TMD}$ & $\mathrm{BDI}$ & + & $\begin{array}{l}\text { significantly higher levels of depression } \\
\text { in patients with painful TMD, } \\
\text { no differences between the study groups }\end{array}$ \\
\hline $\begin{array}{l}\text { Calixtre et al. } \\
(2014)^{43}\end{array}$ & $\begin{array}{l}N=116 \\
32 \text { men } \\
84 \text { women }\end{array}$ & TMD & TMD & $\mathrm{RDC} / \mathrm{TMD}$ & HADS & + & $\begin{array}{l}\text { significant differences found only } \\
\text { in the maximum mouth opening } \\
\text { without pain and the level of self- } \\
\text { estimated mandibular impairment } \\
\text { at the time of higher levels of depression }\end{array}$ \\
\hline $\begin{array}{l}\text { Manfredini et al. } \\
(2009)^{44}\end{array}$ & $\begin{array}{c}N=96 \\
21 \text { men } \\
75 \text { women }\end{array}$ & $\begin{array}{c}\text { TMD } \\
\text { subgroups }\end{array}$ & $\begin{array}{c}\text { TMD } \\
\text { subgroups }\end{array}$ & $\mathrm{RDC} / \mathrm{TMD}$ & SCL-90R & - & no significant correlation found \\
\hline
\end{tabular}

TMD - temporomandibular disorders; RDC/TMD - Research Diagnostic Criteria for Temporomandibular Disorders; DC/TMD - Diagnostic Criteria for Temporomandibular Disorders; HADS - Hospital Anxiety and Depression Scale; DASS-21 - Depression, Anxiety and Stress Scale-21; PHQ-9 - Patient Health Questionnaire-9; SCL-90R - Symptom Checklist-90-Revised; SCL-90 - Symptom Checklist-90; BDI - Beck Depression Inventory.

The odds of TMD correlated with the level of traitanxiety, regardless of age, gender or the level of education. Patients suffering from trait-anxiety at a moderate level were at higher risk of TMD, while severe traitanxiety doubled the risk..$^{53}$

In one of the analyzed articles, higher state-anxiety levels correlated with an increased risk of painful TMD ${ }^{53}$ whereas in another study, they did not. ${ }^{15}$ This inconsistency can be easily explained, because, as mentioned before, state-anxiety concerns the momentarily perceived anxiety, which can be influenced by other psychosocial factors, not taken into consideration in either of the presented articles.

Similarly to depression, anxiety does not show any correlation with Axis I diagnosis, leading to the conclusion that the localization of the symptoms is insignificant. $35,50,53$

There is weak evidence that the level of anxiety tends to decrease significantly after 1 month of treatment, regardless of the type of therapy used (occlusal splint therapy, manual therapy, counseling, or the combination of occlusal splint therapy and counseling). ${ }^{52}$
Table 2 presents a summary of data regarding anxiety from the most important studies included in the review.

\section{Limitations}

The usage of questionnaires as the only diagnostic tools for mental disorders is an important limitation of the included studies. The lack of further psychiatric confirmation may lead to misdiagnosis, biasing the presented results. Furthermore, questionnaires screen only for certain symptoms and do not provide a precise psychiatric diagnosis.

\section{Conclusions}

Evidence supporting a correlation between mental disorders, such as depression and anxiety, and TMD is convincing and numerous. The derangements 
Table 2. Summary of data regarding anxiety from the most important studies included in the review

\begin{tabular}{|c|c|c|c|c|c|c|c|}
\hline Study & Population & $\begin{array}{l}\text { Study } \\
\text { group }\end{array}$ & $\begin{array}{l}\text { Control } \\
\text { group }\end{array}$ & $\begin{array}{c}\text { TMD } \\
\text { diagnosing } \\
\text { tool }\end{array}$ & $\begin{array}{c}\text { Psychiatric } \\
\text { diagnosing } \\
\text { tool }\end{array}$ & Correlation & Conclusion \\
\hline $\begin{array}{l}\text { Giannakopoulos et al. } \\
(2010)^{1}\end{array}$ & $\begin{array}{c}N=222 \\
61 \text { men } \\
161 \text { women }\end{array}$ & $\begin{array}{l}\text { chronic, } \\
\text { painful } \\
\text { TMD }\end{array}$ & $\begin{array}{l}\text { non-painful TMD, } \\
\text { patients without } \\
\text { chronic facial pain }\end{array}$ & $\mathrm{RDC} / \mathrm{TMD}$ & HADS & + & no significant correlation found \\
\hline $\begin{array}{l}\text { Casanova-Rosado et al. } \\
(2006)^{3}\end{array}$ & $N=506$ & TMD & non-TMD & $\mathrm{RDC} / \mathrm{TMD}$ & LS & + & $\begin{array}{l}\text { significantly higher levels of anxiety } \\
\text { in the study group }\end{array}$ \\
\hline $\begin{array}{l}\text { Monteiro et al. } \\
(2011)^{15}\end{array}$ & $\begin{array}{c}N=150 \\
117 \text { men } \\
33 \text { women }\end{array}$ & $\begin{array}{c}\text { TMD } \\
\text { (chronic } \\
\text { orofacial } \\
\text { pain) }\end{array}$ & non-TMD & $\mathrm{RDC} / \mathrm{TMD}$ & STAI & + & $\begin{array}{l}\text { significantly higher levels of trait-anxiety } \\
\text { in the study group }\end{array}$ \\
\hline $\begin{array}{l}\text { Cao et al. } \\
(2020)^{20}\end{array}$ & $N=830$ & $\begin{array}{l}\text { TMD } \\
\text { subgroups }\end{array}$ & $\begin{array}{l}\text { TMD } \\
\text { subgroups }\end{array}$ & $\mathrm{RDC} / \mathrm{TMD}$ & DASS-21 & $+1-$ & $\begin{array}{l}\text { significantly higher levels of anxiety only } \\
\text { in the chronic, painful TMD subgroup }\end{array}$ \\
\hline $\begin{array}{l}\text { Simoen et al. } \\
(2020)^{34}\end{array}$ & $\begin{array}{c}N=243 \\
52 \text { men } \\
191 \text { women }\end{array}$ & $\begin{array}{l}\text { painful } \\
\text { TMD }\end{array}$ & non-TMD & $\mathrm{DC} / \mathrm{TMD}$ & GAD-7 & + & $\begin{array}{l}\text { significantly higher levels of anxiety } \\
\text { in the study group, unrelated to gender }\end{array}$ \\
\hline $\begin{array}{l}\text { De la Torre Canales et al. } \\
(2020)^{36}\end{array}$ & $\begin{array}{c}N=737 \\
150 \text { men } \\
587 \text { women }\end{array}$ & $\begin{array}{l}\text { painful } \\
\text { TMD }\end{array}$ & $\begin{array}{l}\text { non-painful } \\
\text { TMD }\end{array}$ & $\mathrm{RDC} / \mathrm{TMD}$ & SCL-90R & + & no significant correlation found \\
\hline $\begin{array}{l}\text { Machado de Resende et al. } \\
(2020)^{37}\end{array}$ & $\begin{array}{c}N=120 \\
48 \text { men } \\
72 \text { women }\end{array}$ & TMD & non-TMD & $\mathrm{RDC} / \mathrm{TMD}$ & $\begin{array}{l}\text { BAl, STAl, } \\
\text { HADS }\end{array}$ & + & $\begin{array}{l}\text { significantly higher levels of anxiety } \\
\text { in the study group }\end{array}$ \\
\hline $\begin{array}{l}\text { Reiter et al. } \\
(2015)^{38}\end{array}$ & $N=207$ & $\begin{array}{l}\text { chronic } \\
\text { TMD }\end{array}$ & acute TMD & $\mathrm{RDC} / \mathrm{TMD}$ & SCL-90 & - & no significant correlation found \\
\hline $\begin{array}{l}\text { Reissmann et al. } \\
(2014)^{53}\end{array}$ & $\begin{array}{c}N=1,208 \\
436 \text { men } \\
772 \text { women }\end{array}$ & TMD & non-TMD & $\mathrm{RDC} / \mathrm{TMD}$ & STAI & + & $\begin{array}{l}\text { significantly higher levels of anxiety } \\
\text { in the study group }\end{array}$ \\
\hline
\end{tabular}

LS - Likert Scale; STAI - State-Trait Anxiety Inventory; GAD-7 - Generalized Anxiety Disorder-7; BAI - Beck Anxiety Inventory.

influence the onset of TMD, the course of the disease and a response to treatment. However, the precise role of each mental disorder still requires further clarification.

Screening for mental disorders in TMD patients by means of questionnaires in general dentists' offices is highly recommended.

Depression correlates with TMD; the presence or absence of orofacial pain might by a more important factor than a diagnosis of TMD.

A correlation between anxiety and TMD is rather controversial and depends on various factors, such as the study design, the population under study, the control group, etc. Future studies should focus on investigating the circumstances in which the correlation is significant.

In further research, precise causal relationships should be established between depression, anxiety and TMD, along with defining the prevalence and coexistence of the above-mentioned conditions. A diagnosis of mental disorders should be confirmed by psychiatric examination, not only based on questionnaires.

\section{ORCID iDs}

Wojciech Florjański (1) https://orcid.org/0000-0002-6739-1515 Sylwia Orzeszek (1) https://orcid.org/0000-0002-3139-5696

\section{References}

1. Giannakopoulos NN, Keller L, Rammelsberg P, Kronmüller KT, Schmitter M. Anxiety and depression in patients with chronic temporomandibular pain and in controls. J Dent. 2010;38(5):369-376. doi:10.1016/j.jdent.2010.01.003

2. de Godoi Gonçalves DA, Dal Fabbro AL, Bonini Campos JAD, Bigal ME, Speciali JG. Symptoms of temporomandibular disorders in the population: An epidemiological study. $J$ Orofac Pain. 2010;24(3):270-278. PMID:20664828

3. Casanova-Rosado JF, Medina-Solís CE, Vallejos-Sánchez AA, Casanova-Rosado AJ, Hernández-Prado B, Avila-Burgos L. Prevalence and associated factors for temporomandibular disorders in a group of Mexican adolescents and youth adults. Clin Oral Investig. 2006;10(1):42-49. doi:10.1007/s00784-005-0021-4

4. Shiau YY, Chang C. An epidemiological study of temporomandibular disorders in university students of Taiwan. Community Dent Oral Epidemiol. 1992;20(1):43-47. doi:10.1111/j.1600-0528.1992.tb00672.x

5. Pedroni CR, De Oliveira AS, Guaratini MI. Prevalence study of signs and symptoms of temporomandibular disorders in university students. J Oral Rehabil. 2003;30(3):283-289. doi:10.1046/j.13652842.2003.01010.x

6. de Oliveira AS, Dias EM, Contato RG, Berzin F. Prevalence study of signs and symptoms of temporomandibular disorder in Brazilian college students. Braz Oral Res. 2006;20(1):3-7. doi:10.1590/s180683242006000100002

7. Garcia AR, Lacerda N Jr., Pereira SLS. Evaluation of the degree of dysfunction of the temporomandibular joint and of mandibular movements in young adults [in Portuguese]. Rev Assoc Paul Cir Dent. 1997;51:46-51. https://pesquisa.bvsalud.org/portal/resource/ pt/lil-197363. Accessed December 12, 2020.

8. Okeson JP. Management of Temporomandibular Disorders and Occlusion. St. Louis, USA: Mosby; 2013:129-170. 
9. Molin C. From bite to mind: TMD - a personal and literature review. Int J Prosthodont. 1999;12(3):279-288. PMID:10635197

10. Zhang ZK, Ma XC, Gao S, Gu ZY, Fu KY. Studies on contributing factors in temporomandibular disorders. Chin J Dent Res. 1999;2(3-4):7-20. PMID:10863411

11. Greene CS. The etiology of temporomandibular disorders: Implications for treatment. J Orofac Pain. 2001;15(2):93-116. PMID:11443830

12. Suvinen TI, Reade PC, Kemppainen P, Könönen M, Dworkin SF. Review of aetiological concepts of temporomandibular pain disorders: Towards a biopsychosocial model for integration of physical disorder factors with psychological and psychosocial illness impact factors. Eur J Pain. 2005;9(6):613-633. doi:10.1016/j.ejpain.2005.01.012

13. Dworkin SF, LeResche L. Research diagnostic criteria for temporomandibular disorders: Review, criteria, examinations and specifications, critique. J Craniomandib Disord. 1992;6(4):301-355. PMID:1298767

14. Bonjardim LR, Duarte Gavião MB, Pereira LJ, Castelo PM. Anxiety and depression in adolescents and their relationship with signs and symptoms of temporomandibular disorders. Int J Prosthodont. 2005;18(4):347-352. PMID:16052791

15. Monteiro DR, Junqueira Zuim PR, Pesqueira AA, do Pardo Ribeiro $P$ Garcia AR. Relationship between anxiety and chronic orofacial pain of temporomandibular disorder in a group of university students. J Prosthodont Res. 2011;55(3):154-158. doi:10.1016/j.jpor.2010.11.001

16. Slade GD, Diatchenko L, Bhalang K, et al. Influence of psychological factors on risk of temporomandibular disorders. J Dent Res. 2007;86(11):1120-1125. doi:10.1177/154405910708601119

17. Fillingim RB, Ohrbach R, Greenspan JD, et al. Psychological fac tors associated with development of TMD: The OPPERA prospective cohort study. J Pain. 2013;14(12 Suppl):T75-T90. doi:10.1016/j. jpain.2013.06.009

18. Sipilä K, Ylöstalo PV, Joukamaa M, Knuuttila ML. Comorbidity between facial pain, widespread pain, and depressive symptoms in young adults. J Orofac Pain. 2006;20(1):24-30. PMID:16483017

19. Fricton JR, Olsen T. Predictors of outcome for treatment of temporomandibular disorders. J Orofac Pain. 1996;10(1):54-65. PMID:8995917

20. Cao Y, Yap AU, Lei J, Zhang MJ, Fu KY. Subtypes of acute and chronic temporomandibular disorders: Their relation to psychological and sleep impairments. Oral Dis. 2020. doi:10.1111/odi.13692

21. Marbach JJ. The 'temporomandibular pain dysfunction syndrome' personality: Fact or fiction? J Oral Rehabil. 1992;19(6):545-560. doi:10.1111/j.1365-2842.1992.tb01485.x

22. Bruehl H, Rueger M, Dziobek I, et al. Hypothalamic-pituitary-adrenal axis dysregulation and memory impairments in type 2 diabetes. J Clin Endocrinol Metab. 2007;92(7):2439-2445. doi:10.1210/jc.2006-2540

23. Galli U, Gaab J, Ettlin DA, Ruggia F, Ehlert U, Palla S. Enhanced negative feedback sensitivity of the hypothalamus-pituitary-adrenal axis in chronic myogenous facial pain. Eur J Pain. 2009;13(6):600-605. doi:10.1016/j.ejpain.2008.07.010

24. Holsboer F. The corticosteroid receptor hypothesis of depression. Neuropsychopharmacology. 2000;23(5):477-501. doi:10.1016/S0893133X(00)00159-7

25. Staniszewski K, Lygre $\mathrm{H}$, Bifulco $\mathrm{E}$, et al. Temporomandibular disorders related to stress and HPA-axis regulation. Pain Res Manag. 2018;2018:7020751. doi:10.1155/2018/7020751

26. Korszun A, Hinderstein B, Wong M. Comorbidity of depression with chronic facial pain and temporomandibular disorders. Oral Surg Oral Med Oral Pathol Oral Radiol Endod. 1996;82(5):496-500. doi:10.1016/s1079-2104(96)80192-2

27. American Psychiatric Association. Diagnostic and Statistical Manual of Mental Disorders: DSM- $5^{\circledR}$. $5^{\text {th }}$ ed. Arlington, USA: American Psychiatric Association; 2013:155-189.

28. Zimmerman M, McGlinchey JB, Young D, Chelminski I. Diagnosing major depressive disorder I: A psychometric evaluation of the DSM-IV symptom criteria. J Nerv Ment Dis. 2006;194(3):158-163. doi:10.1097/01.nmd.0000202239.20315.16

29. Simon GE, Von Korff M. Medical co-morbidity and validity of DSM-IV depression criteria. Psychol Med. 2006;36(1):27-36. doi:10.1017/ S0033291705006136

30. Williams DR. Characteristics of completed suicides. Psychiatr Times. 2016. https://www.psychiatrictimes.com/view/characteristicscompleted-suicides. Accessed December 10, 2020.
31. Liu Q, He H, Yang J, Feng X, Zhao F, Lyu J. Changes in the global burden of depression from 1990 to 2017: Findings from the Global Burden of Disease study. J Psychiatr Res. 2020;126:134-140. doi:10.1016/j.jpsychires.2019.08.002

32. Daly EJ, Singh JB, Fedgchin $M$, et al. Efficacy and safety of intranasal esketamine adjunctive to oral antidepressant therapy in treatmentresistant depression: A randomized clinical trial. JAMA Psychiatry. 2018;75(2):139-148. doi:10.1001/jamapsychiatry.2017.3739

33. Zhong $\mathrm{X}, \mathrm{He} \mathrm{H}$, Zhang $\mathrm{C}$, et al. Mood and neuropsychological effects of different doses of ketamine in electroconvulsive therapy for treatment-resistant depression. J Affect Disord. 2016;201:124-130. doi:10.1016/j.jad.2016.05.011

34. Simoen L, Van den Berghe L, Jacquet W, Marks L. Depression and anxiety levels in patients with temporomandibular disorders: Comparison with the general population. Clin Oral Investig. 2020;24(11):3939-3945. doi:10.1007/s00784-020-03260-1

35. Kim MJ, Lim MJ, Park WK, Kho HS. Comparison between the SCL-90-R and MMPI in TMD patients with psychological problems. Oral Dis. 2012;18(2):140-146. doi:10.1111/j.1601-0825.2011.01854.x

36. De la Torre Canales G, Bonjardim LR, Poluha RL, et al. Correlation between physical and psychosocial findings in a population of temporomandibular disorder patients. Int J Prosthodont. 2020;33(2):155-159. doi:10.11607/ijp.5847

37. Machado de Resende CMB, da Silva Rocha LGD, de Paiva RP, et al. Relationship between anxiety, quality of life, and sociodemographic characteristics and temporomandibular disorder. Oral Surg Oral Med Oral Pathol Oral Radiol. 2020;129(2):125-132. doi:10.1016/j. oooo.2019.10.007

38. Reiter S, Emodi-Perlman A, Goldsmith C, Friedman-Rubin P, Winocur E. Comorbidity between depression and anxiety in patients with temporomandibular disorders according to the research diagnostic criteria for temporomandibular disorders. J Oral Facial Pain Headache. 2015;29(2):135-143. doi:10.11607/ofph.1297

39. Hoffmann RG, Kotchen JM, Kotchen TA, Cowley T, Dasgupta M, Cowley AW Jr. Temporomandibular disorders and associated clinical comorbidities. Clin J Pain. 2011;27(3):268-274. doi:10.1097/ AJP.0b013e31820215f5

40. Bair MJ, Wu J, Damush TM, Sutherland JM, Kroenke K. Association of depression and anxiety alone and in combination with chronic musculoskeletal pain in primary care patients. Psychosom Med. 2008;70(8):890-897. doi:10.1097/PSY.0b013e318185c510

41. Fernandes G, de Godoi Gonçalves DA, Tesseroli de Siqueira JT, Camparis CM. Painful temporomandibular disorders, self reported tinnitus, and depression are highly associated. Arq Neuropsiquiatr. 2013;71(12):943-947. doi:10.1590/0004-282X20130191

42. Maślak-Bereś M, Loster JE, Wieczorek A, Loster BW. Evaluation of the psychoemotional status of young adults with symptoms of temporomandibular disorders. Brain Behav. 2019;9(11):e01443. doi:10.1002/brb3.1443

43. Calixtre LB, da Silva Grüninger BL, Chaves TC, de Oliveira AB. Is there an association between anxiety/depression and temporomandibular disorders in college students? J Appl Oral Sci. 2014;22(1):15-21. doi:10.1590/1678-775720130054

44. Manfredini D, Marini M, Pavan C, Pavan L, Guarda-Nardini L. Psychosocial profiles of painful TMD patients. J Oral Rehabil. 2009;36(3):193-198. doi:10.1111/j.1365-2842.2008.01926.x

45. Sheng J, Liu S, Wang Y, Cui R, Zhang X. The link between depression and chronic pain: Neural mechanisms in the brain. Neural Plast. 2017;2017:9724371. doi:10.1155/2017/9724371

46. IsHak WW, Wen RY, Naghdechi L, et al. Pain and depression: A systematic review. Harv Rev Psychiatry. 2018;26(6):352-363. doi:10.1097/ HRP.0000000000000198

47. Abdallah CG, Geha P. Chronic pain and chronic stress: Two sides of the same coin? Chronic Stress (Thousand Oaks). 2017;1:2470547017704763. doi:10.1177/2470547017704763

48. Pelkonen ESJ, Mäki PH, Kyllönen MA, Miettunen JA, Taanila AM, Sipilä KK. Pain-related symptoms of temporomandibular disorders in the offspring of antenatally depressed mothers and depressed parents: A 31-year follow-up of the Northern Finland Birth Cohort 1966. Eur J Pain. 2013;17(7):1048-1057. doi:10.1002/j.1532-2149.2012.00270.x 
49. Ströhle A, Gensichen J, Domschke K. The diagnosis and treatment of anxiety disorders. Dtsch Arztebl Int. 2018;155(37):611-620. doi:10.3238/arztebl.2018.0611

50. Spielberger CD, Gorsuch RL, Lushene RE. STAI Manual for the State Trait Anxiety Inventory. Palo Alto, USA: Consulting Psychologists Press, Inc.; 1970:4-6.

51. Wittchen HU, Jacobi F, Rehm J, et al. The size and burden of mental disorders and other disorders of the brain in Europe 2010. Eur Neuropsychopharmacol. 2011;21(9):655-679. doi:10.1016/j.euroneuro.2011.07.018

52. Melo RA, Machado de Resende $C M B$, de Figueirêdo Rêgo $C R$, de Sousa Leite Bispo A, Seabra Barbosa GA, de Almeida EO. Conservative therapies to treat pain and anxiety associated with temporomandibular disorders: A randomized clinical trial. Int Dent J. 2020;70(4):245-253. doi:10.1111/idj.12546

53. Reissmann DR, John MT, Seedorf H, Doering S, Schierz O. Tem poromandibular disorder pain is related to the general disposition to be anxious. J Oral Facial Pain Headache. 2014;28(4):322-330. doi:10.11607/ofph.1277

54. Vassend O, Krogstad BS, Dahl BL. Negative affectivity, somatic complaints, and symptoms of temporomandibular disorders. J Psychosom Res. 1995;39(7):889-899. doi:10.1016/0022-3999(95)00041-9

55. Meldolesi G, Picardi A, Accivile E, Toraldo di Francia R, Biondi M. Personality and psychopathology in patients with temporomandibular joint pain-dysfunction syndrome. A controlled investigation. Psychother Psychosom. 2000;69(6):322-328. doi:10.1159/000012415

56. Fricton JR, Kroening R, Haley D, Siegert R. Myofascial pain syndrome of the head and neck: A review of clinical characteristics of 164 patients. Oral Surg Oral Med Oral Pathol. 1985;60(6):615-623. doi:10.1016/0030-4220(85)90364-0

57. Stockstill JW, Callahan CD. Personality hardiness, anxiety, and depression as constructs of interest in the study of temporomandibular disorders. J Craniomandib Dis. 1991;5(2):129-134. PMID:1812139

58. Marbach JJ, Lund P. Depression, anhedonia and anxiety in temporomandibular joint and other facial pain syndromes. Pain. 1981;11(1):73-84. doi:10.1016/0304-3959(81)90140-8

59. Huang GJ, LeResche L, Critchlow CW, Martin MD, Drangsholt MT. Risk factors for diagnostic subgroups of painful temporomandibular disorders (TMD). J Dent Res. 2002;81(4):284-288. doi:10.1177/154405910208100412

60. Gatchel RJ, Garofalo JP, Ellis E, Holt C. Major psychological disorders in acute and chronic TMD: An initial examination. J Am Dent Assoc. 1996;127(9):1365-1370. doi:10.14219/jada.archive.1996.0450

61. Gerschman JA, Wright JL, Hall WD, Reade PC, Burrows GD, Holwill BJ. Comparisons of psychological and social factors in patients with chronic oro-facial pain and dental phobic disorders. Aust Dent J. 1987;32(5):331-335. doi:10.1111/j.1834-7819.1987.tb00598.x 